\title{
The voltage-dependent potassium channel subunit Kv2.1 regulates insulin secretion from rodent and human islets independently of its electrical function
}

\author{
X. Q. Dai • J. E. Manning Fox • D. Chikvashvili • \\ M. Casimir • G. Plummer • C. Hajmrle • \\ A. F. Spigelman • T. Kin • D. Singer-Lahat • Y. Kang • \\ A. M. J. Shapiro • H. Y. Gaisano • I. Lotan • \\ P. E. MacDonald
}

Received: 29 August 2011 / Accepted: 24 January 2012 /Published online: 13 March 2012

(C) Springer-Verlag 2012

\begin{abstract}
Aims/hypothesis It is thought that the voltage-dependent potassium channel subunit Kv2.1 (Kv2.1) regulates insulin secretion by controlling beta cell electrical excitability. However, this role of Kv2.1 in human insulin secretion has been questioned. Interestingly, Kv2.1 can also regulate exocytosis through direct interaction of its $\mathrm{C}$-terminus with the soluble NSF attachment receptor (SNARE) protein, syntaxin $1 \mathrm{~A}$. We hypothesised that this interaction mediates insulin secretion independently of Kv2.1 electrical function. Methods Wild-type Kv2.1 or mutants lacking electrical function and syntaxin 1A binding were studied in rodent and human beta cells, and in INS-1 cells. Small intracellular fragments of the channel were used to disrupt native Kv2.1syntaxin 1A complexes. Single-cell exocytosis and ion channel currents were monitored by patch-clamp electrophysiology. Interaction between Kv2.1, syntaxin 1A and
\end{abstract}

X. Q. Dai · J. E. Manning Fox • M. Casimir · G. Plummer •

C. Hajmrle · A. F. Spigelman • P. E. MacDonald $(\varangle)$

Alberta Diabetes Institute, University of Alberta,

Edmonton, AB, Canada T6G 2E1

e-mail: pmacdonald@ualberta.ca

D. Chikvashvili $\cdot$ D. Singer-Lahat $\cdot$ I. Lotan

Sackler School of Medicine, Tel Aviv University,

Tel Aviv, Israel

T. Kin $\cdot$ A. M. J. Shapiro

Department of Surgery, University of Alberta,

Edmonton, AB, Canada

Y. Kang $\cdot$ H. Y. Gaisano

Departments of Medicine and Physiology, University of Toronto,

Toronto, ON, Canada other SNARE proteins was probed by immunoprecipitation. Whole-islet $\mathrm{Ca}^{2+}$-responses were monitored by ratiometric Fura red fluorescence and insulin secretion was measured. Results Upregulation of Kv2.1 directly augmented beta cell exocytosis. This happened independently of channel electrical function, but was dependent on the Kv2.1 C-terminal syntaxin 1A-binding domain. Intracellular fragments of the Kv2.1 C-terminus disrupted native Kv2.1-syntaxin 1A interaction and impaired glucose-stimulated insulin secretion. This was not due to altered ion channel activity or impaired $\mathrm{Ca}^{2+}$-responses to glucose, but to reduced SNARE complex formation and $\mathrm{Ca}^{2+}$-dependent exocytosis.

Conclusions/interpretation Direct interaction between syntaxin $1 \mathrm{~A}$ and the Kv2.1 C-terminus is required for efficient insulin exocytosis and glucose-stimulated insulin secretion. This demonstrates that native Kv2.1-syntaxin 1A interaction plays a key role in human insulin secretion, which is separate from the channel's electrical function.

Keywords Exocytosis · Human · Insulin · Ion channel · Islets of Langerhans $\cdot \mathrm{Kv} 2.1 \cdot \mathrm{SNARE}$

$\begin{array}{ll}\text { Abbreviations } \\ \text { Ad } & \text { Adenovirus } \\ \text { BK } & \text { Large-conductance } \mathrm{Ca}^{2+} \text {-sensitive } \mathrm{K}^{+} \\ \text {CHAPS } & \text { 3-[(3-Cholamidopropyl)dimethylammonio]- } \\ & \text { 1-propanesulfonate } \\ \text { GFP } & \text { Green fluorescent protein } \\ \text { GST } & \text { Glutathione S-transferase } \\ \text { Kv } & \text { Voltage-dependent } \mathrm{K}^{+} \\ \text {Kv2.1 } & \text { Voltage-dependent potassium channel subunit } \\ & \text { Kv2.1 }\end{array}$




$\begin{array}{ll}\text { Kv2.1wt } & \text { Wild-type Kv2.1 } \\ \text { MUNC18a } & \text { Mammalian uncoordinated-18a } \\ \text { pEGFP } & \text { Enhanced GFP } \\ \text { pEYFP } & \text { Enhanced yellow fluorescent protein } \\ \text { SNAP-25 } & \text { Synaptosomal-associated protein 25 } \\ \text { SNARE } & \text { Soluble NSF attachment receptor } \\ \text { VAMP2 } & \text { Vesicle-associated membrane protein 2 } \\ \text { YFP } & \text { Yellow fluorescent protein }\end{array}$

\section{Introduction}

The voltage-dependent potassium channel subunit Kv2.1 (Kv2.1) represents a major beta cell voltage-dependent $\mathrm{K}^{+}$ $(\mathrm{Kv})$ channel that contributes to action potential repolarisation in rodents $[1,2]$. The glucose-dependent insulinotropic effect of Kv2.1 inhibition in rodents suggests that this channel could be a useful pharmacological target in diabetes $[3$, 4]. However, while abundant Kv2.1 protein and channel activity are detectable in human islets and beta cells [5-7], the role of this channel in human insulin secretion has been questioned. Pharmacological inhibitors of Kv2.1 block a large fraction of the $\mathrm{Kv}$ current in human beta cells and induce oscillatory $\mathrm{Ca}^{2+}$ responses in human islets, although this effect was small [5]. Kv2.1 inhibitors also have no effect on human beta cell electrical responses and insulin secretion [7], a finding supported by recent mathematical modelling of human beta cell electrical function [8]. Therefore the role of Kv2.1 in insulin secretion, particularly from human islets, remains unclear.

The exocytosis of insulin granules involves the formation of a core soluble NSF attachment receptor (SNARE) protein complex [9], which also serves to localise secretory granules to sites of $\mathrm{Ca}^{2+}$ entry by interacting with voltage-dependent $\mathrm{Ca}^{2+}$ channels [10-12]. Reciprocally, SNARE proteins directly bind and modulate several beta cell ion channels, including voltage-dependent $\mathrm{Ca}^{2+}$ channels $[13,14]$, ATPsensitive $\mathrm{K}^{+}$channels $[15,16]$ and $\mathrm{Kv}$ channels $[17,18]$. Thus, interaction between SNAREs and the excitatory machinery is proposed to localise secretory granules to sites of $\mathrm{Ca}^{2+}$ entry and to shape beta cell excitability during insulin secretion [19]. We previously reported that interactions between Kv2.1 and the SNARE proteins synaptosomalassociated protein 25 (SNAP-25) [17] and syntaxin 1A [18] modulate channel electrical function. More recently, we showed that syntaxin $1 \mathrm{~A}$ binding to a $\mathrm{C}$-terminal domain of Kv2.1 directly facilitates exocytosis in PC12, bovine chromaffin and rat dorsal root ganglion cells following Kv2.1 upregulation [20-22], and that disruption of Kv2.1syntaxin $1 \mathrm{~A}$ interaction impairs noradrenaline (norepinephrine) release from permeabilised PC12 cells [23]. We therefore sought to determine whether Kv2.1 plays a direct role in insulin exocytosis as such in rodent and human beta cells.
Here we show that Kv2.1 associates with syntaxin $1 \mathrm{~A}$ in INS-1 832/13 cells and human islets. Wild-type Kv2.1 (Kv2.1wt) or a non-conducting pore mutant caused similar increases in beta cell exocytosis, while a Kv2.1 mutant lacking the syntaxin 1A-binding domain did not. Disruption of native Kv2.1-syntaxin 1A interaction by a cytosolic Kv2.1 C-terminal fragment reduced glucose-stimulated insulin secretion due to impaired assembly of the SNARE complex and $\mathrm{Ca}^{2+}$-dependent exocytosis. Thus the present work addresses the discrepancy between the presence of Kv2.1 in human beta cells and the apparent lack of effect of Kv2.1 current inhibition on human insulin secretion. We demonstrate that a native Kv2.1-syntaxin $1 \mathrm{~A}$ interaction plays a key role in insulin release and that this is independent of channel electrical function.

\section{Methods}

Cells and cell culture INS-1 832/13 cells were cultured at $37^{\circ} \mathrm{C}$ and $5 \% \mathrm{CO}_{2}$ in RPMI-1640 containing (in mmol/l): 11.1 glucose, 10 HEPES, 2 L-glutamine, 1 sodium pyruvate, along with $10 \% \mathrm{FBS}, 50 \mu \mathrm{mol} / 1 \beta$-mercaptoethanol and 100 units $/ \mathrm{ml}$ penicillin/streptomycin. Cells were transfected using Lipofectamine 2000 (Invitrogen, Carlsbad, CA, USA) and plated in $35 \mathrm{~mm}$ culture dishes. Mouse islets were obtained by collagenase digestion from male C57/b16 mice. Human islets from 22 healthy donors $(46.2 \pm 2.3$ years) were from the Clinical Islet Laboratory at the University of Alberta and the Alberta Diabetes Institute IsletCore. Islets were dispersed to single cells by shaking in $\mathrm{Ca}^{2+}$-free buffer and plated in $35 \mathrm{~mm}$ dishes. Mouse islets and cells were cultured in RPMI-1640 with $10 \%$ FBS and 100 units $/ \mathrm{ml}$ penicillin-streptomycin. Human islets and cells were cultured in low-glucose $(1 \mathrm{~g} / \mathrm{l})$ DMEM with L-glutamine, $10 \%$ FBS and 100 units $/ \mathrm{ml}$ penicillin-streptomycin. All studies were approved by the Animal Care and Use Committee and the Human Research Ethics Board at the University of Alberta.

Constructs, adenoviruses and recombinant peptides The $\mathrm{Kv} 2.1$ pore mutant $\left(\mathrm{Kv} 2.1^{\mathrm{W} 365 \mathrm{C} / \mathrm{Y} 380 \mathrm{~T}}\right)$ and construct lacking the syntaxin-binding domain $\left(\mathrm{Kv} 2.1^{\mathrm{W} 365 \mathrm{C} / \mathrm{Y} 380 \mathrm{~T}} \Delta \mathrm{C} 1 \mathrm{a}\right)$ have been described previously [20] (Fig. 1a). Kv2.1wt, $\mathrm{Kv} 2.1^{\mathrm{W} 365 \mathrm{C} / \mathrm{Y} 380 \mathrm{~T}}$ and $\mathrm{Kv} 2.1^{\mathrm{W} 365 \mathrm{C} / \mathrm{Y} 380 \mathrm{~T}} \Delta \mathrm{C} 1 \mathrm{a}$ were all cloned by PCR into pAdtrackCMV, which co-produces green fluorescent protein (GFP) to allow identification of transfected cells. The glutathione S-transferase (GST)tagged Kv2.1 peptide fragments (GST-Kv2.1-N, GST$\mathrm{Kv} 2.1-\mathrm{C} 1$ and GST-Kv2.1-C2) were produced as previously reported [17]. Untagged versions of these, for mammalian expression, were generated via PCR from Kv2.1wt and cloned into pcDNA3.1. Forward and reverse primers 
a

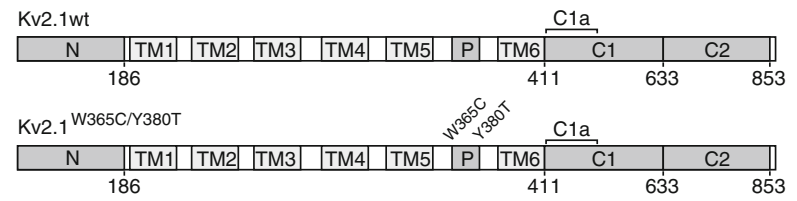

b
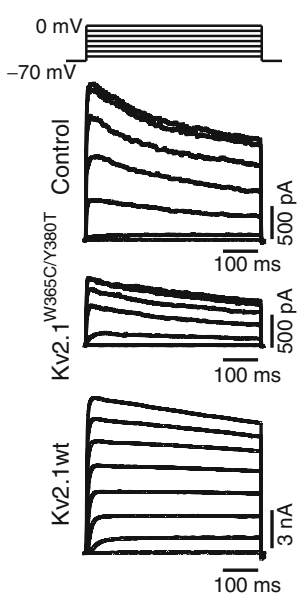

C

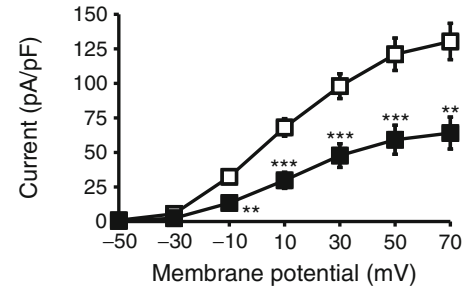

d

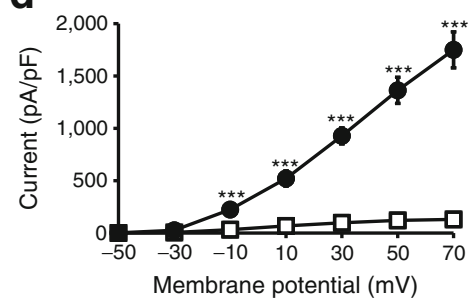

e

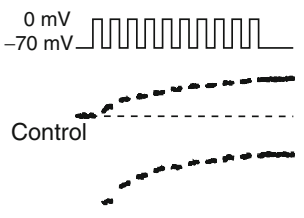

$\mathbf{f}$

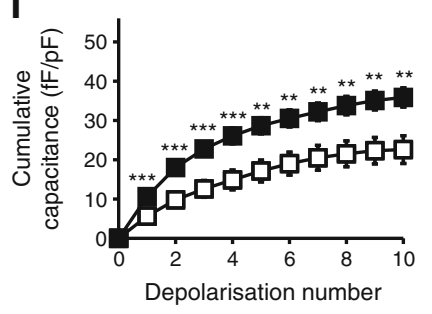

g

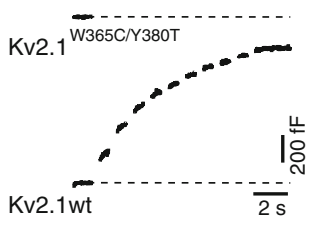

allow identification of transfected cells. Kv2.1-C1 was also cloned into enhanced yellow fluorescent protein (pEYFP)$\mathrm{C} 1$ to generate Kv2.1-C1-YFP. Finally, using the AdEasy system (www.coloncancer.org/adeasy.htm), the C1 fragment clone was used to generate a recombinant adenovirus (Ad-GFP-Kv2.1-C1), which also co-produces GFP. An adenovirus (Ad) producing GFP alone (Ad-GFP) was used as a control. All constructs were confirmed by sequencing.

Insulin secretion assay Insulin secretion measurements were performed at $37^{\circ} \mathrm{C}$ in $\mathrm{KRB}$ containing (in $\mathrm{mmol} / \mathrm{l}$ ): $135 \mathrm{NaCl}, 3.6 \mathrm{KCl}, 5 \mathrm{NaHCO}_{3}, 1.5 \mathrm{CaCl}_{2}, 0.5 \mathrm{MgCl}_{2}, 0.5$ $\mathrm{NaH}_{2} \mathrm{PO}_{4}, 10$ HEPES and $0.1 \%$ BSA (pH 7.4). Some 10 to 20 islets per group were pre-incubated for $2 \mathrm{~h}$ in $2.8 \mathrm{mmol} /$ 1 glucose KRB, then for an additional $1 \mathrm{~h}$ in this buffer, followed by $1 \mathrm{~h}$ with $16.7 \mathrm{mmol} / \mathrm{l}$ glucose KRB. The supernatant fractions were collected and the islets lysed in acidethanol for insulin content. Samples were stored at $-20^{\circ} \mathrm{C}$ and assayed for insulin via ELISA (ALPCO, Salem, NH, USA). Results are expressed as insulin released as a percentage of total insulin content and compared by paired Student's $t$ test. Two human islet preparations were excluded due to baseline hypersecretion ( $>2 \%$ of content released at low glucose).

Immunoprecipitation and immunoblotting For experiments in Fig. 2, INS-1 $832 / 13$ cells $\left(30 \times 10^{6}\right.$ cells per reaction) were homogenised in ice-cold buffer containing, in addition to protease inhibitor cocktail, the following in mmol/l: 150 $\mathrm{NaCl}$, 50 TRIS-HCl, 5 EDTA, 1 EGTA, and either 1\% freshly prepared 3-[(3-cholamidopropyl)dimethylammonio]-1-propanesulfonate (CHAPS) (Fig. 2a,b) or 1\% Triton X-100 (Fig. 2c,d). Homogenates were incubated for $2 \mathrm{~h}$ and centrifuged, both at $4{ }^{\circ} \mathrm{C}$, for $25 \mathrm{~min}$ at $12,000 \mathrm{rpm}$. The supernatant fraction was purified by protein A-sepharose and $1 \% \mathrm{BSA}$ for $1 \mathrm{~h}$ and immunoprecipitated for $4 \mathrm{~h}$ with syntaxin 1A or Kv2.1 antibodies (Alomone Labs, Tel Aviv, Israel) that were prebound to protein A immobilised on sepharose. In Fig. 2c,d, immunoprecipitation with Kv2.1 antibody was performed in the presence of $10 \mu \mathrm{mol} / \mathrm{l} \mathrm{GST}$ fusion peptides Kv1.1-C (C terminus of Kv1.1 known not to bind syntaxin 1A) or Kv2.1-C1. Glutathione-sepharose beads were added to the supernatant fraction of the immunoprecipitation reactions to pull down syntaxin $1 \mathrm{~A}$ together with the GST-fusion peptides. These were washed three times in PBS containing either $0.2 \%$ CHAPS (Fig. $2 a, b$ ) or $0.1 \%$ Triton X100 (Fig. 2c,d). The inclusion of 5\% glycerol in the final wash minimised the non-specific interactions between syntaxin $1 \mathrm{~A}$ and protein A-sepharose beads. The bound GST-fusion proteins were eluted with reduced glutathione as described [20]. For controls, cell lysates were immunoprecipitated with an irrelevant antibody ( $\mathrm{IgG}$ ) and with protein A-sepharose alone, or by performing the immunoprecipitation with Kv2.1 antibody in the presence of its antigen peptide (1:1 ratio).

These were co-transfected with enhanced GFP ( $\mathrm{pEGFP)}$ to 

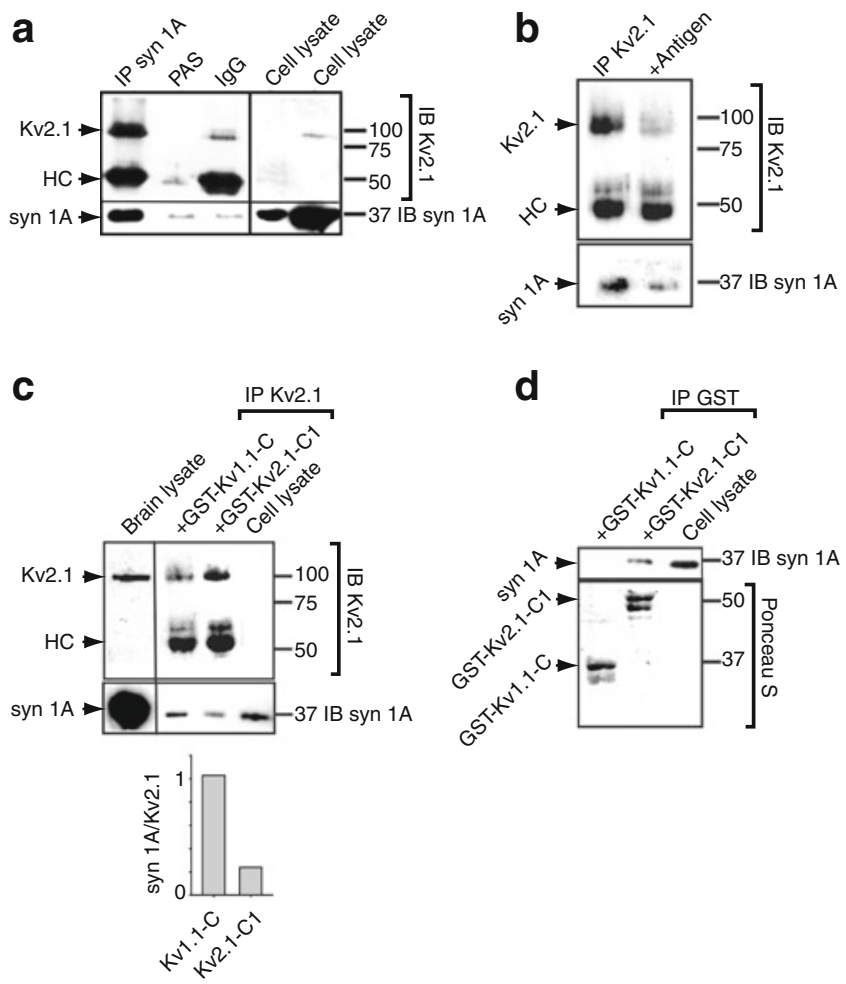

Fig. 2 The Kv2.1 C1 domain mediates channel binding to syntaxin 1A in insulinoma cells. Reciprocal co-immunoprecipitation (IP) of (a) syntaxin 1A (syn 1A) and (b) Kv2.1, using syntaxin 1A and Kv2.1 antibodies in INS-1 $832 / 13$ cells $\left(30 \times 10^{6}\right.$ cells). Immunoprecipitation with an irrelevant antibody (IgG) and with protein A-sepharose alone (PAS) served as controls. Lysates (no immunoprecipitation performed) from $1.8 \times 10^{6}$ cells for Kv2.1 detection and from $1.5 \times 10^{4}$ cells for syntaxin $1 \mathrm{~A}$ detection were loaded (cell lysate) for comparison. HC, IgG heavy chain. $\mathbf{c}$ In the presence of Kv2.1-derived syntaxin 1Abinding peptide (GST-Kv2.1 C1), co-immunoprecipitation of syntaxin $1 \mathrm{~A}$ with Kv2.1 using Kv2.1 antibody was disrupted. The non-syntaxin 1A-binding peptide, GST-Kv1.1 C, served as a control. A blot with quantification of the extent of syn $1 \mathrm{~A}$ co-immunoprecipitation with Kv2.1 is shown. d Pull-down of GST-Kv2.1 C1 peptide, but not GST$\mathrm{Kv} 1.1 \mathrm{C}$ resulted in pull-down of syntaxin 1A. The Kv2.1 antibody (Alomone) used in these experiments recognises a C-terminal epitope (amino acids 841-857) that does not overlap with the $\mathrm{C} 1$ domain

SNARE complex pull-down in INS-1 832/13 cells was examined as described previously [24] following stimulation with $16.7 \mathrm{mmol} / \mathrm{l}$ glucose for $30 \mathrm{~min}$ to stimulate SNARE complex formation. Human islet immunoprecipitations were washed three times with cold PBS and homogenised in icecold CelLytic M lysis reagent (Sigma-Aldrich, Oakville, ON, Canada) with protease inhibitor cocktail. Homogenates were incubated for $2 \mathrm{~h}$ at $4^{\circ} \mathrm{C}$ and centrifuged for $10 \mathrm{~min}$ at $\quad 4^{\circ} \mathrm{C}$ and at $16,000 \mathrm{~g}$. Equal amounts of total protein from postnuclear supernatant fractions were pre-cleared for $1 \mathrm{~h}$ with protein G-sepharose, and then incubated for $4 \mathrm{~h}$ under gentle shaking and overnight, with antibody for syntaxin 1A (Santa Cruz Biotechnology, Santa Cruz, CA, USA) or Kv2.1 (NeuroMab, Davis, CA, USA) and also under gentle shaking, at $4^{\circ} \mathrm{C}$. The immune complexes absorbed to protein G-sepharose were washed five times with NP-40 buffer (containing in mmol/l: $150 \mathrm{NaCl}, 50$ TRIS-base and $1 \%$ Igepal) at $4^{\circ} \mathrm{C}$.

Precipitated proteins were analysed by western blotting using antibodies against Kv2.1 (NeuroMab; Alomone Labs), syntaxin 1A (Sigma-Aldrich; Santa Cruz Biotechnology; Alomone Labs), mammalian uncoordinated-18a (MUNC18a) (BC Biosciences, Mississauga, ON, Canada), SNAP-25 (Sternberger Monoclonals, Baltimore, MD, USA) and vesicleassociated membrane protein 2 (VAMP2) (a gift from A. Lowe, Stanford University School of Medicine, Stanford, CA, USA). Primary antibodies were incubated overnight at $4^{\circ} \mathrm{C}$, followed by three washes of $10 \mathrm{~min}$ each, after which secondary antibodies were used for $1.5 \mathrm{~h}$ at room temperature. Then blots were exposed to electrochemiluminescence (ECL; GE Healthcare, Piscataway, NJ, USA). GST-fusion proteins were detected by staining with ponceau S (Fig. 2d). At least three experiments were performed, with representative examples shown, except in Fig. 2c,d $(n=2)$.

Patch-clamp electrophysiology The standard whole-cell technique with the sine+DC lock-in function of an EPC10 amplifier and Patchmaster software (HEKA Electronics, Lambrecht/Pfalz, Germany) was used in experiments performed at $32^{\circ} \mathrm{C}$ to $35^{\circ} \mathrm{C}$. Patch pipettes, pulled from borosilicate glass and coated with Sylgard, had a resistance of 3 to $4 \mathrm{M} \Omega$ when filled with pipette solution; liquid junction potentials were corrected as appropriate.

For depolarisation-stimulated capacitance measurements, the pipette solution contained (in mmol/l): 125 Cs-glutamate, $10 \mathrm{CsCl}, 10 \mathrm{NaCl}, 1 \mathrm{MgCl}_{2} 6 \mathrm{H}_{2} \mathrm{O}, 0.05$ EGTA, 5 HEPES, 0.1 cAMP and $3 \mathrm{Mg}$ ATP (pH 7.15 with $\mathrm{CsOH}$ ). The extracellular bath contained (in mmol/l): $118 \mathrm{NaCl}, 20$ tetraethylammonium chloride, $5.6 \mathrm{KCl}, 1.2 \mathrm{MgCl}_{2} 6 \mathrm{H}_{2} \mathrm{O}, 2.6 \mathrm{CaCl}_{2}, 5$ glucose and 5 HEPES ( $\mathrm{pH} 7.4$ with $\mathrm{NaOH}$ ). For measurement of voltage-dependent $\mathrm{Ca}^{2+}$ currents, the pipette solution was (in mmol/l): 140 Cs-glutamate, $1 \mathrm{MgCl}_{2}, 20$ tetraethylammonium chloride, 5 EGTA, 20 HEPES and 3 MgATP (pH 7.3 with $\mathrm{CsOH}$ ). The extracellular bath contained (in mmol/l): 10 $\mathrm{BaCl}_{2}, 100 \mathrm{NaCl}, 5 \mathrm{CsCl}, 1 \mathrm{MgCl}_{2}, 5$ glucose, 10 HEPES, and $0.5 \mu \mathrm{mol} / 1$ tetrodotoxin ( $\mathrm{pH} 7.35$ with $\mathrm{CsOH}$ ). When exocytosis was initiated by dialysis of a $\mathrm{Ca}^{2+} /$ EGTA-buffer ( $200 \mathrm{nmol} / 1$ free $\mathrm{Ca}^{2+}$ ), the intracellular solution contained (in mmol/l): $125 \mathrm{~K}$-glutamate, $10 \mathrm{NaCl}, 10 \mathrm{KCl}, 1 \mathrm{MgCl}_{2} 6 \mathrm{H}_{2} \mathrm{O}, 5$ $\mathrm{CaCl}_{2}, 10$ EGTA, 5 HEPES and $3 \mathrm{MgATP}(\mathrm{pH} 7.1$ with $\mathrm{KOH}$ ). The extracellular solution contained (in mmol/l): $138 \mathrm{NaCl}$, $5.6 \mathrm{KCl}, 1.2 \mathrm{MgCl}_{2} 6 \mathrm{H}_{2} \mathrm{O}, 2.6 \mathrm{CaCl}_{2}, 5$ glucose and 5 HEPES (pH 7.4 with $\mathrm{NaOH}$ ). For $\mathrm{Kv}$ currents, the intracellular solution contained (in mmol/l): $140 \mathrm{KCl}, 1 \mathrm{CaCl}_{2}, 1 \mathrm{MgCl}_{2}, 10$ HEPES, 10 EGTA and 3 MgATP (pH 7.3 with $\mathrm{KOH}$ ). The bath solution was composed of (in mmo/l): $135 \mathrm{NaCl}, 5.4 \mathrm{KCl}$, $1 \mathrm{CaCl}_{2}, 1.2 \mathrm{MgCl}_{2}, 10$ HEPES and 5 glucose $(\mathrm{pH} 7.3$ with $\mathrm{NaOH})$. 
Measurements were normalised to initial cell size and expressed as femtofarad $(\mathrm{fF})$ per picofarad $(\mathrm{pF})$ and picoampere $(\mathrm{pA})$ per $\mathrm{pF}$. Mouse beta cells were identified by size and the presence of a voltage-gated $\mathrm{Na}^{+}$current that inactivates at approximately $-90 \mathrm{mV}$ [25], while human beta cells were positively identified by insulin immunostaining.

$\mathrm{Ca}^{2+}$ imaging Islets infected with Ad-GFP or Ad-GFP$\mathrm{Kv} 2.1-\mathrm{C} 1$ and cultured for 24 to $48 \mathrm{~h}$ were incubated for 45 min with $10 \mu \mathrm{mol} / 1$ Fura Red-AM and $0.08 \%$ pluronic acid (Invitrogen, Burlington, ON, Canada) in a $\mathrm{Ca}^{2+}$ imaging solution containing (in mmol/l): $130 \mathrm{NaCl}, 5 \mathrm{KCl}, 2$ $\mathrm{CaCl}_{2}, 1 \mathrm{MgCl}_{2}, 5 \mathrm{NaHCO}_{3}, 0.5$ glucose and 10 HEPES ( $\mathrm{pH} 7.4$ with $\mathrm{NaOH}$ ). Islets were then imaged in fresh imaging solution with $0.5 \mathrm{mmol} / \mathrm{l}$ glucose and without Fura Red-AM or pluronic acid at $37^{\circ} \mathrm{C}$ with constant bath perfusion. Imaging was performed with a Stallion imaging system (Olympus Canada, Richmond Hill, ON, Canada). Image acquisition and analysis was with Ratio Cam software (Metamorph, Molecular Devices, Sunnyvale, CA, USA). Excitation was at 440 and $490 \mathrm{~nm}$. Emission was collected using a $660 / 50 \mathrm{~nm}$ bandpass filter for ratiometric imaging. Glucose $(11 \mathrm{mmol} / \mathrm{l})$ was increased as indicated and the $\mathrm{NaCl}$ concentration reduced as required.

\section{Results}

Kv2.1 facilitates human beta cell exocytosis independently of its ability to conduct $\mathrm{K}^{+}$We produced Kv2.1wt and a nonconducting pore mutant $\left(\mathrm{Kv} 2.1^{\mathrm{W} 365 \mathrm{C} / \mathrm{Y} 380 \mathrm{~T}}\right)$ in human beta cells (Fig. 1a). Transfected cells were identified by coproduced GFP. The dominant-negative Kv2.1 ${ }^{\mathrm{W} 365 \mathrm{C} / \mathrm{Y} 380 \mathrm{~T}}$ reduced human beta cell $\mathrm{Kv}$ currents by $50.1 \%$ at $70 \mathrm{mV}$ to $64 \pm$ $12 \mathrm{pA} / \mathrm{pF}(n=15, p<0.01)$ (Fig. 1b,c), which was consistent with previous reports of functional native Kv2.1 channels in these cells [5-7]. The wild-type channel increased the $\mathrm{Kv}$ current by 13.4 -fold to $1749 \pm 172 \mathrm{pA} / \mathrm{pF}(n=12, p<0.001)$ (Fig. 1b,d). Despite the opposing effects of Kv2.1wt and $\mathrm{Kv} 2.1^{\mathrm{W} 365 \mathrm{C} / \mathrm{Y} 380 \mathrm{~T}}$ on channel currents, both enhanced the exocytotic response of human beta cells to a train of membrane depolarisations (Fig. 1e-g). Total exocytosis was increased from $24.1 \pm 3.6 \mathrm{fF} / \mathrm{pF}$ in GFP controls $(n=18)$ to 48.8 $\pm 6.8 \mathrm{fF} / \mathrm{pF}$ in the presence of $\mathrm{Kv} 2.1 \mathrm{wt}(n=19, p<0.01)$. Similarly, the presence of $\mathrm{Kv} 2.1^{\mathrm{W} 365 \mathrm{C} / \mathrm{Y} 380 \mathrm{~T}}$ increased total exocytosis from $22.6 \pm 3.5 \mathrm{fF} / \mathrm{pF}$ (GFP controls; $n=25$ ) to 35.9 $\pm 2.4 \mathrm{fF} / \mathrm{pF}(n=39, p<0.01)$. Therefore, Kv2.1 facilitates human beta cell exocytosis in response to depolarisation, regardless of the channel's ability to conduct $\mathrm{K}^{+}$current.

The Kv2.1 C-terminus regulates exocytosis from INS-1 cells In INS-1 832/13 cells we found that Kv2.1 coimmunoprecipitated together with syntaxin 1A (Fig. 2a) and vice versa (Fig. 2b), demonstrating interaction between these native proteins. Since syntaxin $1 \mathrm{~A}$ binds the Kv2.1 Cterminus at the C1a region [26], we examined whether the Kv2.1-syntaxin 1A interaction could be disrupted using the Kv2.1-derived syntaxin 1A binding peptide GST-Kv2.1-C1 [27]. This approach is similar to that used to demonstrate coupling of exocytosis to $\mathrm{Ca}^{2+}$ channels $[10,28-30]$. Immunoprecipitation with anti-Kv2.1 in the presence of GSTKv2.1-C1 or GST-Kv1.1-C (negative control) demonstrated that the Kv2.1-C1 fragment efficiently uncoupled the Kv2.1-syntaxin 1A interaction (Fig. 2c). This was due to competitive binding of GST-Kv2.1-C1 to syntaxin 1A, as pull-down of GST-bound proteins from the immunoprecipitation supernatant fraction (Fig. 2d) demonstrated binding of syntaxin 1A to the GST-Kv2.1-C1 peptide. Thus, syntaxin $1 \mathrm{~A}$ binds to $\mathrm{Kv} 2.1$ at its $\mathrm{C}$-terminus in insulinsecreting cells, and a small C-terminal fragment of the channel competitively disrupts this interaction.

We then generated an electrically inactive Kv2.1 channel lacking the syntaxin 1A-binding domain (Kv2.1 $\left.{ }^{\mathrm{W} 365 \mathrm{C} / \mathrm{Y} 380 \mathrm{~T}} \Delta \mathrm{C} 1 \mathrm{a}\right)$ (Fig. 3a) [20]. This construct is produced at similar levels to the full-length pore mutant and traffics to the cell surface [20] (data not shown), and inhibits native $\mathrm{Kv}$ currents (Fig. 3b,c), demonstrating the appropriate abundance and dominantnegative function of $\mathrm{Kv} 2.1^{\mathrm{W} 365 \mathrm{C} / \mathrm{Y} 380 \mathrm{~T}} \Delta \mathrm{C} 1 \mathrm{a}$. Similarly to the situation in human beta cells, the presence of $\mathrm{Kv} 2.1^{\mathrm{W} 365 \mathrm{C} / \mathrm{Y} 380 \mathrm{~T}}$ in INS-1 $832 / 13$ cells augmented the exocytotic response, from $14.6 \pm 3.6 \mathrm{fF} / \mathrm{pF}$ in controls $(n=8)$ to $29.0 \pm 3.6 \mathrm{fF} / \mathrm{pF}(n=13, p<0.05)$ (Fig. $3 \mathrm{~d}, \mathrm{e})$. However, Kv2.1 ${ }^{\text {W365C/Y380T }} \Delta \mathrm{C} 1 \mathrm{a}$, which lacks the syntaxin 1A-binding domain, had no effect on exocytosis $(n=11)$.

The role of a native Kv2.1-syntaxin 1A interaction in INS$1832 / 13$ cell exocytosis was investigated by producing untagged versions of Kv2.1 C-terminal (Kv2.1-C1 and -C2) and $\mathrm{N}$-terminal $(\mathrm{Kv} 2.1-\mathrm{N})$ fragments (in pcDNA3.1 and cotransfected with pEGFP) (Fig. 4a). The presence of Kv2.1C1 in INS- $1832 / 13$ cells inhibited the Kv current by $41 \%$ ( $n=$ 22, $p<0.001$ ) (Fig. 4b,c). This is contrary to the effective inhibition of exocytosis in INS-1 832/13 cells by Kv2.1-C1 (reduced to $2.4 \pm 0.8 \mathrm{fF} / \mathrm{pF} ; n=31, p<0.001$ ) (Fig. 4d,e). While $\mathrm{Kv} 2.1-\mathrm{C} 2$ had a small but significant effect on $\mathrm{Kv}$ currents $(n=8, p<0.05)$, neither it nor the Kv2.1-N fragment altered INS-1 832/13 cell exocytotic responses $(n=17,18)$ (Fig. 4be). Kv2.1-C1 disrupted native syntaxin $1 \mathrm{~A}-\mathrm{Kv} 2.1$ binding in INS-1 832/13 cells (Fig. 4f,g), also resulting in impaired SNARE complex assembly following glucose-stimulation, as indicated by reduced co-immunoprecipitation of MUNC18a, SNAP-25 and VAMP2 $(n=3)$ (Fig. 4f,g). Finally, we found that fluorescently tagged Kv2.1-C1 (Kv2.1-C1YFP) also inhibited exocytosis in INS-1 832/13 cells $(n=6-8)$ (Fig. 4e) and localised to the plasma membrane (the nuclear 

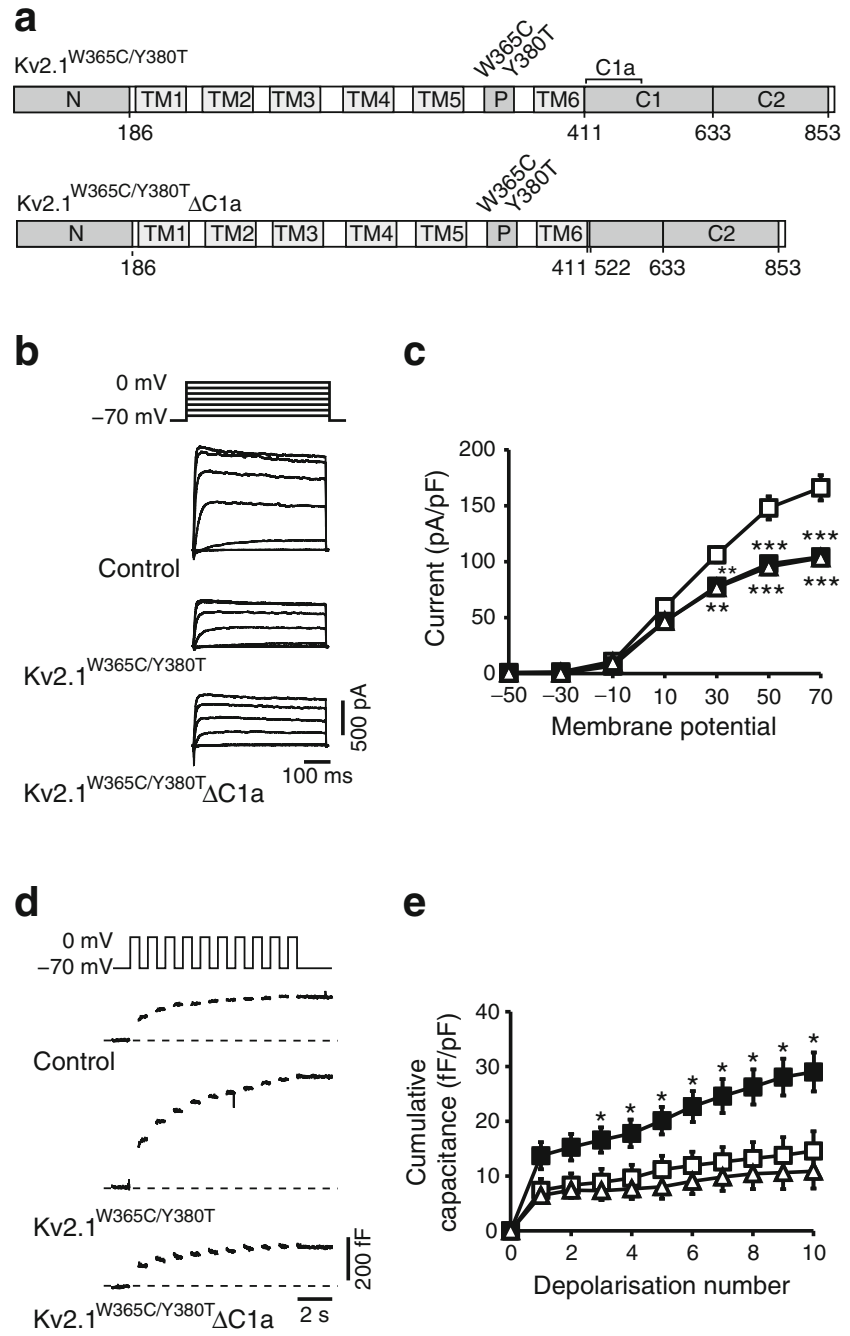

Fig. 3 The Kv2.1 C1a domain mediates the facilitation of exocytosis by Kv2.1 in insulinoma cells. a The Kv2.1 pore mutant (Kv2.1 ${ }^{\text {W365C/Y380T }}$ ) was modified to remove the $\mathrm{C} 1$ a syntaxin 1A-binding domain $\left(\mathrm{Kv} 2.1^{\mathrm{W} 365 \mathrm{C} / \mathrm{Y} 380 \mathrm{~T}} \Delta \mathrm{C} 1 \mathrm{a}\right) . \mathbf{b}$, $\mathbf{c}$ The Kv current was elicited in response to increasing membrane depolarisations from $-70 \mathrm{mV}$. Representative traces (b) and averaged current-voltage relationships (c) are shown. Both channel constructs showed an equivalent dominant-negative function in inhibiting endogenous Kv currents in INS-1 832/13 cells. White squares, GFP alone; black squares, GFP with $\mathrm{Kv} 2.1^{\mathrm{W} 365 \mathrm{C} / \mathrm{Y} 380 \mathrm{~T}}$; white triangles, $\mathrm{Kv} 2.1^{\mathrm{W} 365 \mathrm{C} / \mathrm{Y} 380 \mathrm{~T}} \Delta \mathrm{C} 1 \mathrm{a} . \mathbf{d}$, e Exocytosis was monitored in INS-1 832/13 cells as increases in cell capacitance in response to a series of ten $500 \mathrm{~ms}$ depolarisations from -70 to $0 \mathrm{mV}$. Representative traces (d) and averaged capacitance responses (e) are shown. ${ }^{*} p<0.05,{ }^{*} p<0.01$ and ${ }^{* * *} p<$ 0.001 compared with control

localisation observed is likely to be because the size of this construct is close to that for passive nuclear transport, rather than due to direct nuclear targeting as such [Fig. 4h]).

The ability of Kv2.1-C1 to inhibit exocytosis in INS-1 $832 / 13$ cells was not due to impaired $\mathrm{Ca}^{2+}$ channel activity, since voltage-dependent $\mathrm{Ca}^{2+}$ currents were preserved following disruption of the Kv2.1-syntaxin $1 \mathrm{~A}$ interaction by Kv2.1C1 $(n=20)$ (Fig. 5a,b). Furthermore, the exocytotic response of INS-1 832/13 cells to direct infusion of $200 \mathrm{nmol} / 1 \mathrm{Ca}^{2+}$, bypassing a need for depolarisation and $\mathrm{Ca}^{2+}$ channel activity, remained impaired after production of Kv2.1-C1 (38.0 11.8 $\mathrm{fF} / \mathrm{pF}, n=8)$ compared with a GFP-only control $(88.9 \pm 18.8 \mathrm{fF} /$ pF; $n=8, p<0.05$ ) (Fig. 5c,d). Thus endogenous Kv2.1, specifically the $\mathrm{Cla}$ domain, augments $\mathrm{Ca}^{2+}$-dependent exocytosis in insulin-secreting cells.

Disruption of native Kv2.1-syntaxin $1 A$ interaction impairs beta cell exocytosis and glucose-stimulated insulin secretion To assess the effect of acute disruption of Kv2.1-syntaxin 1A binding, recombinant GST-tagged peptide fragments mimicking the Kv2.1-C1, -C2 and Nterminal domains were generated [17]. We infused GSTKv2.1-C1, GST-Kv2.1-C2 and GST-Kv2.1-N peptides (and GST as a control; $4 \mu \mathrm{g} / \mathrm{ml}$ for $2-3 \mathrm{~min}$ ) directly into mouse beta cells (Fig. 6a) and found that GST-Kv2.1-C1, which competitively disrupted Kv2.1-syntaxin 1A binding (Fig. 2), acutely impaired the exocytotic response of mouse beta cells to membrane depolarisation $(6.9 \pm 1.8 \mathrm{fF} / \mathrm{pF}, n=21)$ compared with GST alone $(19.4 \pm 2.0 \mathrm{fF} / \mathrm{pF} ; n=35, p<0.001)$ (Fig. 6). Consistent with our observations in INS-1 832/13 cells (Fig. 3), the GST-Kv2.1-C2 $(n=16)$ and GST-Kv2.1-N $(n=16)$ peptides had no acute effect on exocytosis (Fig. 6).

To further explore the role of the Kv2.1-syntaxin 1A interaction in primary beta cells and intact islets, we generated a recombinant adenovirus producing the $\mathrm{Kv} 2.1-\mathrm{C} 1$ fragment and co-producing GFP (Ad-GFP-Kv2.1-C1). The presence of Ad-GFP-Kv2.1-C1 impaired glucose-dependent insulin secretion by $38 \%(n=5, p<0.01)$ compared with a GFP control (Ad-GFP) (Fig. 7a). This occurred in the face of an inhibition of whole-cell $\mathrm{Kv}$ currents by $23.5 \%(n=20$, $p<0.05$ at $70 \mathrm{mV}$ ) (Fig. $7 \mathrm{~b}, \mathrm{c}$ ), and a resultant increase in the peak $(p<0.01)$ and total $(p<0.05) \mathrm{Ca}^{2+}$ response to glucose $(n=17-21)$ (Fig. 7d-f). This effect on $\mathrm{Ca}^{2+}$ is consistent with the role of Kv2.1 electrical function in mouse islet $\mathrm{Ca}^{2+}$ responses [2], but cannot account for impaired insulin secretion. Consistent with a direct role of Kv2.1-syntaxin 1A binding in facilitating exocytosis, disruption of that binding with Ad-GFP-Kv2.1-C1 impaired the exocytotic response of mouse beta cells $(n=17, p<0.001)$ (Fig. $7 \mathrm{~g}, \mathrm{~h})$.

Finally, we demonstrated in intact human islets that AdGFP-Kv2.1-C1 reduced native Kv2.1-syntaxin 1A binding, as detected by immunoprecipitation of Kv2.1 (Fig. 8a) or syntaxin 1A (Fig. 8b). This resulted in a $47 \%$ reduction in glucose-stimulated insulin secretion $(n=7$ donors; $p<0.05)$ (Fig. 8c), without alteration of the intracellular $\mathrm{Ca}^{2+}$ response ( $n=7-10$ islets from three donors) (Fig. $8 \mathrm{c}$, inset). At the level of single human beta cells, the total exocytotic response was reduced from $40.8 \pm 7.2 \mathrm{fF} / \mathrm{pF}$ in controls $(n=19)$ to $9.8 \pm 2.2$ $\mathrm{fF} / \mathrm{pF}$ upon production of $\mathrm{Kv} 2.1-\mathrm{C} 1 \quad(n=16, p<0.001)$ (Fig. 8d,e). Consistent with an impairment of $\mathrm{Ca}^{2+}$-dependent exocytosis as such, the inhibitory effect of Ad-GFP-Kv2.1-C1 could not be overcome by increasing the duration of 
a

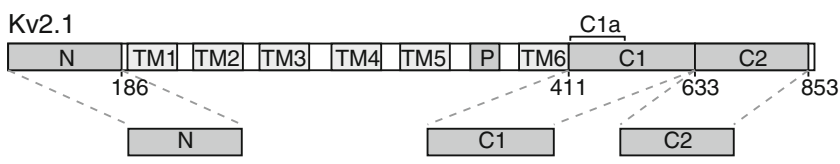

d

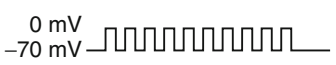

b

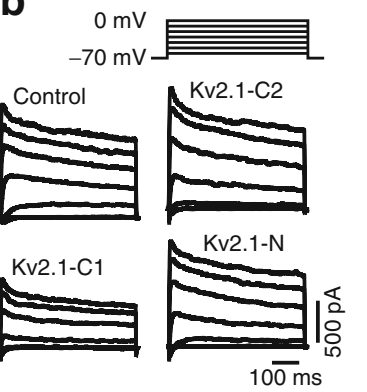

C

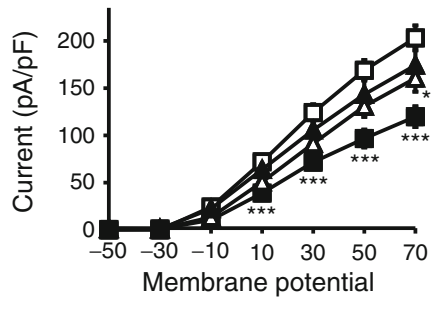

e

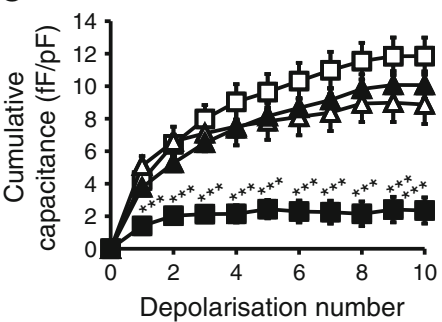

f


g

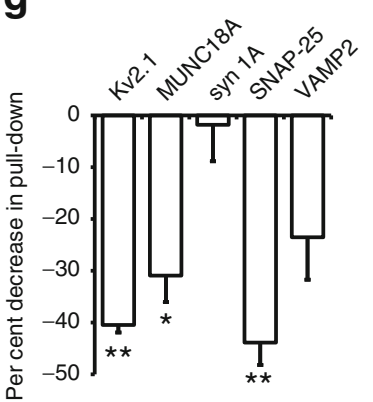

h

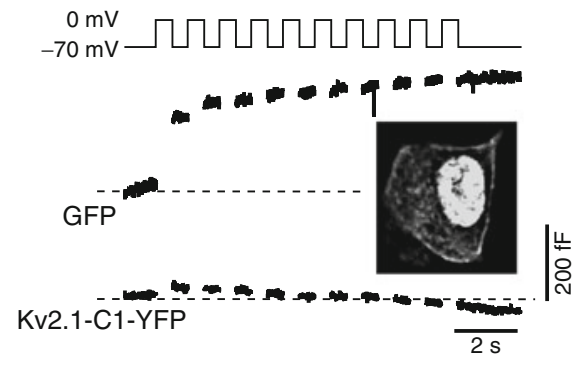

Fig. 4 Exocytosis in INS-1832/13 cells is blunted by introduction of the Kv2.1-C1 syntaxin 1A-binding domain. a Fragments of the Kv2.1 $\mathrm{N}$-terminus $(\mathrm{N})$ and $\mathrm{C}$-terminus $(\mathrm{C} 1$ and $\mathrm{C} 2)$ were cloned for expression in mammalian cells by transient transfection and co-transfected with pEGFP. b, $\mathbf{c}$ The Kv current was elicited in response to increasing membrane depolarisations from $-70 \mathrm{mV}$. Representative traces (b) and averaged current-voltage relationships (c) are shown. d, e Exocytosis was monitored as increases in cell capacitance in response to a series of ten $500 \mathrm{~ms}$ depolarisations from -70 to $0 \mathrm{mV}$. Representative traces (d) and averaged capacitance responses (e) are shown. White squares, GFP alone; black squares, GFP with Kv2.1-C1; white triangles, Kv2.1-C2; black triangles, Kv2.1-N. f Kv2.1-C1 production in INS-1 832/13 cells

membrane depolarisations, a protocol that increases global $\mathrm{Ca}^{2+}$ influx [31]. The exocytotic response to even the longest depolarisation $(2.5 \mathrm{~s})$ was reduced from $17.5 \pm 2.8 \mathrm{fF} / \mathrm{pF}$ in controls $(n=22)$ to $5.0 \pm 1.7 \mathrm{fF} / \mathrm{pF}$ following $\mathrm{Kv} 2.1-\mathrm{C} 1$ production $(n=23, p<0.001)$ (Fig. 8f,g).

\section{Discussion}

The inhibition of beta cell repolarising $\mathrm{K}^{+}$currents prolongs the action potential, increases $\mathrm{Ca}^{2+}$ entry and enhances does not affect the abundance of Kv2.1 or SNARE proteins, but does disrupt syntaxin 1A (syn 1A) binding to Kv2.1 and prevent SNARE complex assembly in INS-1 832/13 cells. Representative blots and (g) averaged data, as the per cent change in pull-down following Kv2.1-C1 production, are shown. The Kv2.1 antibody (NeuroMab) used in this experiment recognises a C-terminal epitope (amino acids 837-853) that does not overlap with the $\mathrm{C} 1$ domain. $\mathbf{h}$ Capacitance responses in INS-1 832/13 cells producing GFP or a YFP-tagged Kv2.1-C1 fragment (representative of 6-8 experiments). Inset: the membrane localisation of Kv2.1-C1-YFP (the observed nuclear localisation is likely to be due to passive nuclear transport of this small construct). ${ }^{*} p<0.05,{ }^{* *} p<0.01$ and ${ }^{* * *} p<0.001$ compared with control or syn $1 \mathrm{~A}$ insulin secretion in rodents and humans [3, 7, 32]. Among likely contributors, the Kv2.1 isoform has been found to mediate the majority of $\mathrm{Kv}$ currents in rodent beta cells [2, $4,33]$, although one or more other channels also contribute [34]. Inhibition or knockout of Kv2.1 enhances the electrical, intracellular $\mathrm{Ca}^{2+}$ and secretory responses of rodent islets $[1,2,4]$. Kv2.1 is also highly abundant and mediates large $\mathrm{K}^{+}$currents in human beta cells $[5-7,35]$, consistent with our observation using the dominant-negative channel (Fig. 1). However, the role of Kv2.1 in human beta cell electrical activity, overall $\mathrm{Ca}^{2+}$ responsiveness and insulin 
a

b

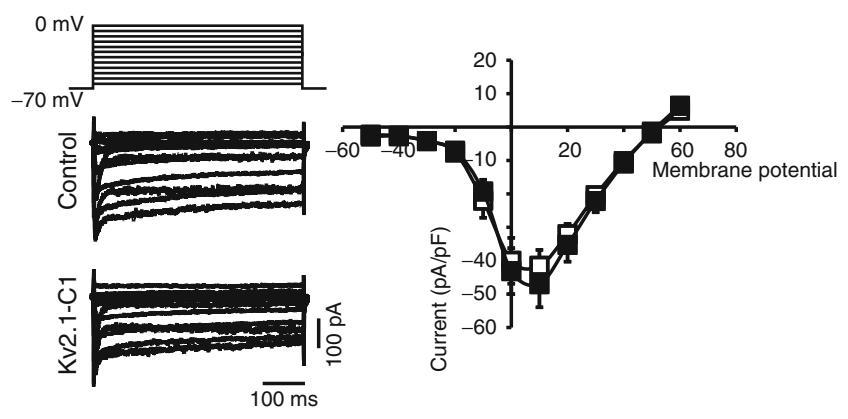

C
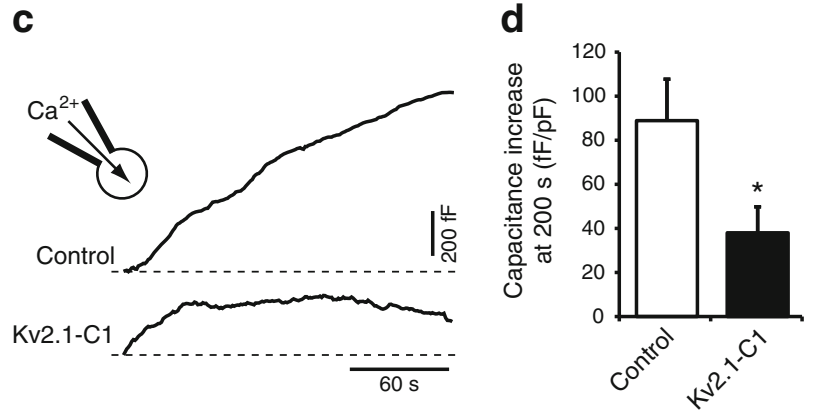

Fig. 5 The $\mathrm{Kv} 2.1-\mathrm{C} 1$ fragment impairs $\mathrm{Ca}^{2+}$-dependent exocytosis, but not $\mathrm{Ca}^{2+}$-channel activity in INS-1 832/13 cells. a, b The voltagedependent $\mathrm{Ca}^{2+}$ current was elicited in response to increasing membrane depolarisations from $-70 \mathrm{mV}$. Representative traces (a) and averaged current-voltage relationships (b) are shown for cells producing GFP alone (Control, white squares) or GFP together with Kv2.1C1 (black squares). c, $\mathbf{d}$ Exocytosis was monitored as increases in cell capacitance in response to the direct infusion of $200 \mathrm{nmol} / 1$ free- $\mathrm{Ca}^{2+}$. Representative traces (c) and averaged capacitance responses at $200 \mathrm{~s}$ (d) are shown. ${ }^{*} p<0.05$ compared with control

secretion appears minimal $[5,7,8]$, while large-conductance $\mathrm{Ca}^{2+}$-sensitive $\mathrm{K}^{+}$(BK) channels may predominate [7].

Kv2.1 interacts with exocytotic SNARE proteins, including SNAP-25 [17] and syntaxin 1A [18], and co-localises with these in lipid rafts [36, 37]. For the most part, these interactions have been studied in the context of SNAREdependent modulation of electrical excitability [19]. Only recently has the converse been examined, namely the question of whether this interaction controls exocytosis itself. Increasing Kv2.1 enhances exocytosis in PC12 and bovine chromaffin cells due to an interaction between the channel $\mathrm{C}$-terminus (specifically, the $\mathrm{C} 1 \mathrm{a}$ domain) and syntaxin $1 \mathrm{~A}$ $[20,22]$. This effect is lost upon disruption of Kv2.1-syntaxin $1 \mathrm{~A}$ binding, either by deletion of the $\mathrm{Cla}$ domain in the channel or introduction of a small peptide (i.e. a Kv2.1$\mathrm{C} 1$ or $\mathrm{C} 1 \mathrm{a}$ peptide) that competes for syntaxin $1 \mathrm{~A}$ binding [20]. This latter approach has been used to probe native Kv2.1-syntaxin 1A interaction in PC12 cells [23] and the coupling of exocytosis to voltage-dependent $\mathrm{Ca}^{2+}$ channels $[10,28-30]$.

Kv2.1 augments exocytosis in INS-1 cells and human beta cells. Several lines of evidence observed by us here suggest that this occurs independently of the channel's electrical function. First, the ability to augment exocytosis was preserved in pore-mutated channels that do not conduct $\mathrm{K}^{+}$. Second, the methods used circumvent any effect of the channel on membrane potential (i.e. the membrane potential is 'voltage-clamped' and $\mathrm{K}^{+}$is replaced with $\mathrm{Cs}^{+}$). Third, the impaired insulin secretion and exocytotic responses observed in the presence of $\mathrm{Kv} 2.1-\mathrm{C} 1$ are in direct contrast to increased (mouse) or unaltered (human) $\mathrm{Ca}^{2+}$ responses. Thus reduced insulin secretion following disruption of the Kv2.1-syntaxin 1A interaction is due to an effect down-stream of glucosedependent $\mathrm{Ca}^{2+}$ entry, consistent with an important role for this complex in insulin exocytosis.

Our data suggest that Kv2.1 plays a role as a direct facilitator of $\mathrm{Ca}^{2+}$-dependent exocytosis and that this is independent of any effect on $\mathrm{Ca}^{2+}$ responses. This, together a

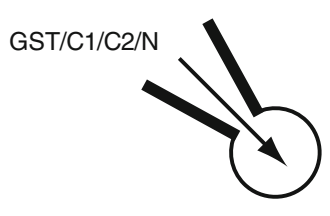

b



C

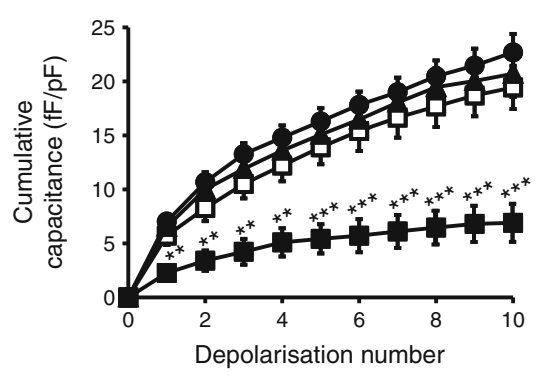

Fig. 6 Acute introduction of the Kv2.1-C1 syntaxin 1A-binding domain impairs exocytosis in primary mouse beta cells. a Purified GST (as a control), GST-Kv2.1-C1 (C1), GST-Kv2.1-C2 (C2) or GST$\mathrm{Kv} 2.1-\mathrm{N}(\mathrm{N})$ were infused directly into mouse beta cells via the patch-clamp pipette $(4 \mu \mathrm{g} / \mathrm{ml}, \sim 3 \mathrm{~min})$. b Exocytosis was monitored as increases in cell capacitance in response to a series of ten $500 \mathrm{~ms}$ depolarisations from -70 to $0 \mathrm{mV}$. c Averaged capacitance responses are shown for cells infused with GST (white squares), GST-Kv2.1-C1 (black squares), GST-Kv2.1-C2 (black circles) and GST-Kv2.1-N (black triangles). ${ }^{* *} p<0.01$ and ${ }^{* * *} p<0.001$ compared with control 
a

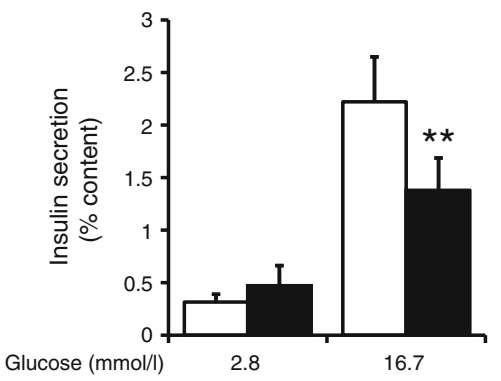

b

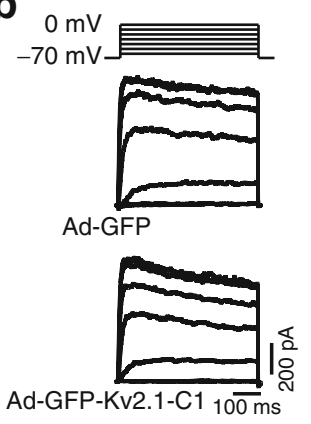

C

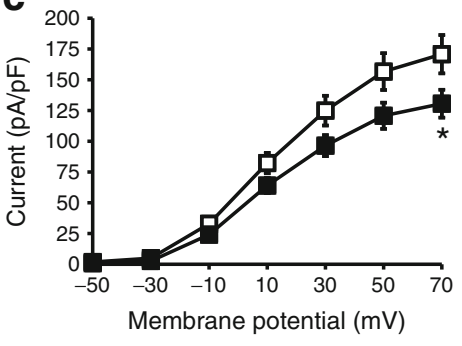

d

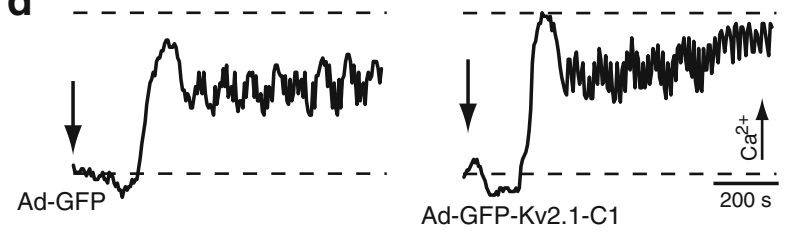

e
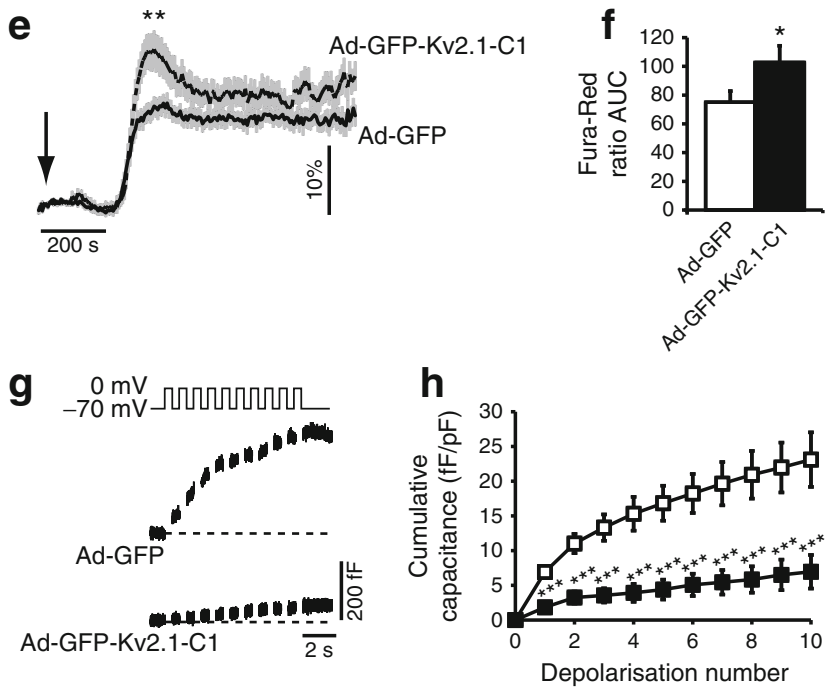

with observations that $\mathrm{Ca}^{2+}$ currents themselves were unaffected by $\mathrm{Kv} 2.1-\mathrm{C} 1$, suggests that impaired $\mathrm{Ca}^{2+}$-signalling is unlikely to be responsible for the reduced exocytotic and secretory response. Indeed, deletion of the syntaxin 1A binding domain of the channel [20] completely abolished Kv2.1-dependent facilitation of exocytosis (Fig. 3d,e), despite preserved production, localisation [20] and dominantnegative function. Furthermore, a native Kv2.1-syntaxin 1A
Fig. 7 Disruption of native Kv2.1-syntaxin 1A binding impairs mouse islet insulin secretion by blunting beta cell exocytosis, but not islet $\mathrm{Ca}^{2+}$ responses. a Compared with Ad-GFP (white bars), glucosestimulated insulin secretion from mouse islets is impaired by Ad-GFPKv2.1-C1 (black bars). b, c The Kv current was elicited in response to increasing membrane depolarisations from $-70 \mathrm{mV}$. Representative traces (b) and averaged current-voltage relationships (c) are shown. White squares, Ad-GFP; black squares, Ad-GFP-Kv2.1-C1. d-f Intracellular $\mathrm{Ca}^{2+}$ responses were monitored by ratiometric Fura-Red fluorescence. Representative traces are shown (d). The averaged $\mathrm{Ca}^{2+}$ responses (e) and AUC (f) are also shown. g, h Exocytosis was monitored as increases in cell capacitance in response to a series of ten $500 \mathrm{~ms}$ depolarisations from -70 to $0 \mathrm{mV}$. Representative traces (g) and averaged capacitance responses (h) are shown. ${ }^{*} p<0.05,{ }^{* *} p<$ 0.01 and $* * * p<0.001$ compared with control

interaction was observed by us in INS- 1 cells and human islets, the importance of which is demonstrated by a 40 to $50 \%$ reduction in glucose-stimulated insulin secretion upon disruption of syntaxin $1 \mathrm{~A}$ binding to the channel. The observation that this reduction in secretion was less than the $75 \%$ reduction in $\mathrm{Ca}^{2+}$-dependent exocytosis was not unexpected and is likely to be due to a combination of factors: (1) a limited infection efficiency in intact islets; (2) an increased $\mathrm{Ca}^{2+}$ response in mouse islets (indeed in human islets, where $\mathrm{Ca}^{2+}$ was unaffected, the inhibition of insulin secretion by Ad-GFPKv2.1-C1 was greater); and (3) the use of direct membrane depolarisation (exocytosis) versus glucosestimulation (secretion), which would generate additional secretory signals [38].

Therefore, in addition to its role in electrical and $\mathrm{Ca}^{2+}$ responses, we have shown that native Kv2.1 plays a direct role in insulin exocytosis by binding syntaxin 1A. Kv2.1 has been proposed to stabilise the acceptor t-SNARE complex [22]. While further work is required to understand the contribution of the Kv2.1-syntaxin 1A interaction to the dynamics underlying this process, we have nonetheless demonstrated a role for native Kv2.1syntaxin $1 \mathrm{~A}$ interaction in beta cell exocytosis. Further support for a role of Kv2.1 at the exocytotic site is provided by the demonstration that Kv2.1 associates with SNARE proteins in beta cell lipid rafts, the disruption of which enhanced exocytosis [36]. Additional work will also be required to determine the impact of Kv2.1 on granule trafficking [39], the relative contributions of pre-docked versus 'newcomer' secretory granules [40] and on the fusion process itself $[41,42]$.

Finally, it should be noted that beta cells from $K v 2.1$ (also known as Kcnb1)-null mice showed enhanced electrical activity, $\mathrm{Ca}^{2+}$ responses and insulin secretion [2]. While this is in agreement with the role of Kv2.1 as a negative modulator of insulin secretion in rodents [3], it is in apparent contradiction to the data presented here. However, the enhanced secretion following Kv2.1 

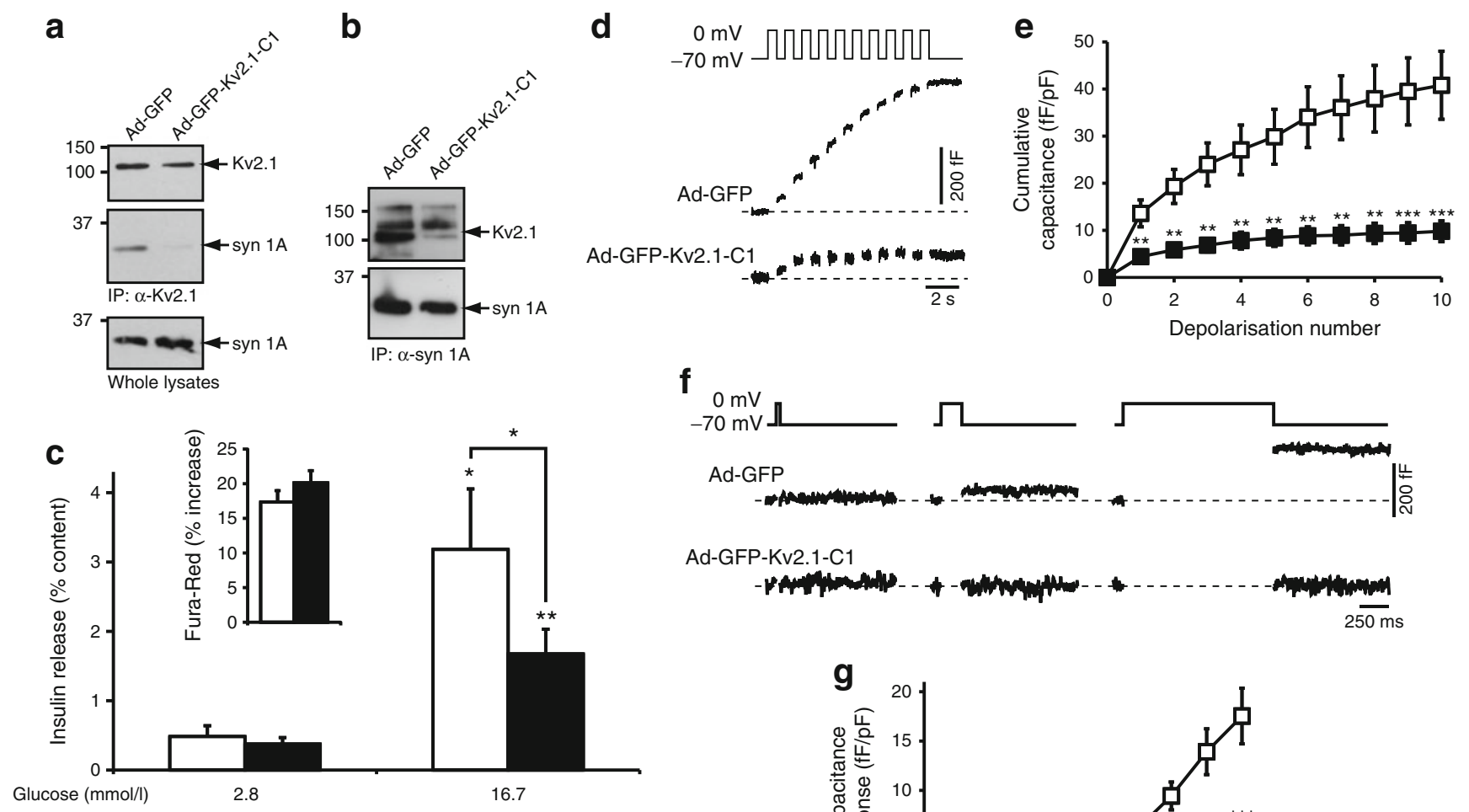

f

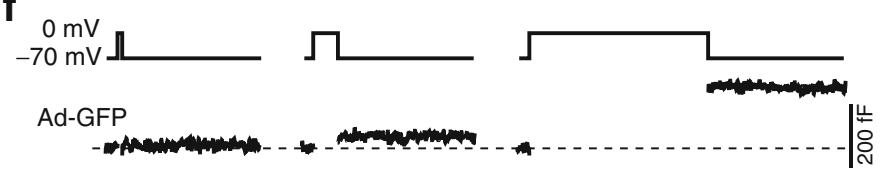

Ad-GFP-Kv2.1-C1
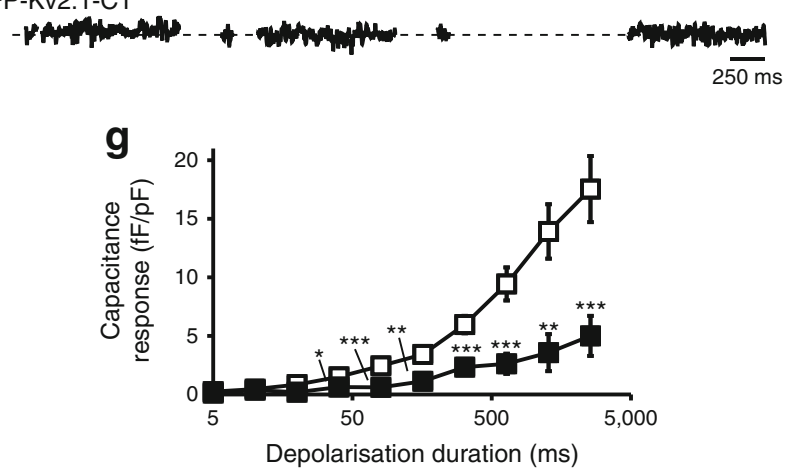

Fig. 8 Disruption of Kv2.1-syntaxin 1A binding in human islets impairs glucose-stimulated insulin secretion by direct inhibition of beta cell exocytosis. Reciprocal co-immunoprecipitation (IP) of (a) Kv2.1 and (b) syntaxin 1A (syn 1A) in human islets. Kv2.1 binding to syntaxin $1 \mathrm{~A}$ is dissociated by the Kv2.1 C1 fragment. The Kv2.1 antibody (NeuroMab) used in this experiment recognises a C-terminal epitope (amino acids 837-853) that does not overlap with the $\mathrm{C} 1$ domain. c Glucose-stimulated insulin secretion from human islets, shown as the percentage of insulin content, is blunted by dissociation of Kv2.1-syntaxin 1A binding with Ad-GFP-Kv2.1-C1 (black bars) compared with Ad-GFP alone (white bars). The percentage

knockout was in response to modest glucose stimulation, while a role for Kv2.1 in exocytosis as such may be more important at higher glucose levels or upon prolonged stimulation. Furthermore, it remains unknown whether compensatory alterations (such as increased SNARE abundance) might promote exocytotic function upon global Kv2.1 knockout. Thus, Kv2.1 may play multiple roles in the regulation of insulin secretion, namely as a regulator of electrical function and in the direct modulation of exocytosis. While the predominant role may be dependent on the timing and nature of the stimulus, we would suggest a key role in exocytosis in human beta cells, given that another channel (the BK channel) probably fulfils a primary role in action potential repolarisation here [7]. increase in intracellular $\mathrm{Ca}^{2+}$, monitored by ratiometric Fura-Red imaging, following glucose stimulation is also shown. d, e Exocytosis was monitored as increases in cell capacitance in response to a series of ten $500 \mathrm{~ms}$ depolarisations from -70 to $0 \mathrm{mV}$. Representative traces (d) and averaged capacitance responses (e) are shown. White squares, AdGFP alone; black squares, Ad-GFP-Kv2.1-C1. f, g Exocytosis was monitored in response to a series of depolarisations from -70 to $0 \mathrm{mV}$ of increasing duration. Representative traces (f) and averaged capacitance responses (g) are shown. ${ }^{*} p<0.05,{ }^{* *} p<0.01$ and ${ }^{* * *} p<$ 0.001 compared with control or as indicated

In conclusion, we have demonstrated that Kv2.1 facilitates beta cell exocytotic responses in rodents and humans by binding to syntaxin 1A. Disruption of native Kv2.1syntaxin $1 \mathrm{~A}$ interaction impairs $\mathrm{Ca}^{2+}$-dependent exocytosis and reduces glucose-stimulated insulin secretion. This is independent of the channel's $\mathrm{K}^{+}$conducting activity and suggests that, apart from a role in electrical function and $\mathrm{Ca}^{2+}$ responses, $\mathrm{Kv} 2.1$ is an important regulator of $\mathrm{Ca}^{2+}$. dependent exocytosis in beta cells. Whether these roles are dynamic or changing over the course of the secretory process remains to be determined. Nonetheless, the present work demonstrates that Kv2.1 plays a role in the regulation of insulin exocytosis that is relevant in human beta cells, where it remains unclear whether this channel has an electrical function. 
Acknowledgements The authors wish to thank N. Smith for excellent technical assistance and C. Newgard (Sarah W. Stedman Metabolism and Nutrition Centre, Duke University, Durham, NC, USA) for providing the INS-1 832/13 cells.

Funding This work was funded by grants to H.Y. Gaisano from the Canadian Institutes of Health Research (CIHR; MOP69083), to I. Lotan from the United States-Israel Bi-national Science Foundation (2009049) and the Israel Academy of Sciences and Humanities (99/10), and to P.E. MacDonald from the CIHR (MOP244739), the National Sciences and Engineering Research Council (NSERC) of Canada, and the Alberta Diabetes Foundation. X.Q. Dai and M. Casimir were supported by fellowships from the Alberta Innovates-Health Solutions (AI-HS). C. Hajmrle was supported by a doctoral studentship from AI-HS. P.E. MacDonald is an AI-HS Scholar and holds the Canada Research Chair in Islet Biology.

Contribution statement XQD, JEMF, YK, DC, MC, GP, TK, CH, AFS, DSL, IL, HYG and PEM conceived and performed experiments, and analysed and interpreted data. TK, AMJS, HYG, IL and PEM conceived experiments, and provided analysis and interpreted data. PEM wrote and edited the manuscript. All authors contributed to the revision of manuscript content and approved the final version.

Duality of interest The authors declare that there is no duality of interest associated with this manuscript.

\section{References}

1. MacDonald PE, Sewing S, Wang J et al (2002) Inhibition of Kv2.1 voltage-dependent $\mathrm{K}^{+}$channels in pancreatic beta-cells enhances glucose-dependent insulin secretion. J Biol Chem 277:4493844945

2. Jacobson DA, Kuznetsov A, Lopez JP, Kash S, Ammala CE, Philipson LH (2007) Kv2.1 ablation alters glucose-induced islet electrical activity, enhancing insulin secretion. Cell Metab 6:229235

3. MacDonald PE, Wheeler MB (2003) Voltage-dependent $\mathrm{K}^{+}$channels in pancreatic beta cells: role, regulation and potential as therapeutic targets. Diabetologia 46:1046-1062

4. Herrington J (2007) Gating modifier peptides as probes of pancreatic beta-cell physiology. Toxicon 49:231-238

5. Tamarina NA, Kuznetsov A, Fridlyand LE, Philipson LH (2005) Delayed-rectifier $\left(\mathrm{K}_{\mathrm{V}} 2.1\right)$ regulation of pancreatic beta-cell calcium responses to glucose: inhibitor specificity and modeling. Am J Physiol Endocrinol Metab 289:E578-E585

6. Herrington J, Sanchez M, Wunderler D et al (2005) Biophysical and pharmacological properties of the voltage-gated potassium current of human pancreatic beta-cells. J Physiol 567:159-175

7. Braun M, Ramracheya R, Bengtsson M et al (2008) Voltage-gated ion channels in human pancreatic beta-cells: electrophysiological characterization and role in insulin secretion. Diabetes 57:1618 1628

8. Pedersen MG (2010) A biophysical model of electrical activity in human beta-cells. Biophys J 99:3200-3207

9. Gerber SH, Sudhof TC (2002) Molecular determinants of regulated exocytosis. Diabetes 51(Suppl 1):S3-S11

10. Wiser O, Trus M, Hernandez A et al (1999) The voltage sensitive Lc-type $\mathrm{Ca}^{2+}$ channel is functionally coupled to the exocytotic machinery. Proc Natl Acad Sci U S A 96:248-253

11. Atlas D (2001) Functional and physical coupling of voltagesensitive calcium channels with exocytotic proteins: ramifications for the secretion mechanism. J Neurochem 77:972-985

12. Yang SN, Larsson O, Branstrom R et al (1999) Syntaxin 1 interacts with the $\mathrm{L}(\mathrm{D})$ subtype of voltage-gated $\mathrm{Ca}^{2+}$ channels in pancreatic beta cells. Proc Natl Acad Sci U S A 96:10164-10169

13. Wiser O, Bennett MK, Atlas D (1996) Functional interaction of syntaxin and SNAP-25 with voltage-sensitive L- and N-type $\mathrm{Ca}^{2+}$ channels. EMBO J 15:4100-4110

14. Arien H, Wiser O, Arkin IT, Leonov H, Atlas D (2003) Syntaxin $1 \mathrm{~A}$ modulates the voltage-gated L-type calcium channel $\left(\mathrm{Ca}_{\mathrm{v}} 1.2\right)$ in a cooperative manner. J Biol Chem 278:29231-29239

15. Pasyk EA, Kang Y, Huang X, Cui N, Sheu L, Gaisano HY (2004) Syntaxin-1A binds the nucleotide-binding folds of sulphonylurea receptor 1 to regulate the $\mathrm{K}_{\mathrm{ATP}}$ channel. J Biol Chem 279:42344240

16. Cui N, Kang Y, He Y et al (2004) H3 domain of syntaxin 1A inhibits $\mathrm{K}_{\mathrm{ATP}}$ channels by its actions on the sulfonylurea receptor 1 nucleotide-binding folds- 1 and -2. J Biol Chem 279:53259-53265

17. MacDonald PE, Wang G, Tsuk S et al (2002) Synaptosomeassociated protein of 25 kilodaltons modulates Kv2.1 voltagedependent $\mathrm{K}^{+}$channels in neuroendocrine islet beta-cells through an interaction with the channel $\mathrm{N}$ terminus. Mol Endocrinol 16:2452-2461

18. Leung YM, Kang Y, Gao X et al (2003) Syntaxin 1A binds to the cytoplasmic $\mathrm{C}$ terminus of $\mathrm{Kv} 2.1$ to regulate channel gating and trafficking. J Biol Chem 278:17532-17538

19. Leung YM, Kwan EP, Ng B, Kang Y, Gaisano HY (2007) SNAREing voltage-gated $\mathrm{K}^{+}$and ATP-sensitive $\mathrm{K}^{+}$channels: tuning beta-cell excitability with syntaxin-1 A and other exocytotic proteins. Endocr Rev 28:653-663

20. Singer-Lahat D, Sheinin A, Chikvashvili D et al (2007) $\mathrm{K}^{+}$channel facilitation of exocytosis by dynamic interaction with syntaxin. J Neurosci 27:1651-1658

21. Feinshreiber L, Singer-Lahat D, Ashery U, Lotan I (2009) Voltagegated potassium channel as a facilitator of exocytosis. Ann N Y Acad Sci 1152:87-92

22. Feinshreiber L, Singer-Lahat D, Friedrich R et al (2010) Nonconducting function of the Kv2.1 channel enables it to recruit vesicles for release in neuroendocrine and nerve cells. J Cell Sci 123:1940-1947

23. Singer-Lahat D, Chikvashvili D, Lotan I (2008) Direct interaction of endogenous $\mathrm{Kv}$ channels with syntaxin enhances exocytosis by neuroendocrine cells. PLoS One 3:e1381

24. Dai XQ, Plummer G, Casimir M et al (2011) SUMOylation regulates insulin exocytosis downstream of secretory granule docking in rodents and humans. Diabetes 60:838-847

25. Gopel SO, Kanno T, Barg S, Weng XG, Gromada J, Rorsman P (2000) Regulation of glucagon release in mouse alpha-cells by $\mathrm{K}_{\text {ATP }}$ channels and inactivation of TTX-sensitive $\mathrm{Na}^{+}$channels. J Physiol 528:509-520

26. Tsuk S, Michaelevski I, Bentley GN, Joho RH, Chikvashvili D, Lotan I (2005) Kv2.1 channel activation and inactivation is influenced by physical interactions of both syntaxin $1 \mathrm{~A}$ and the syntaxin 1A/soluble N-ethylmaleimide-sensitive factor-25 (t-SNARE) complex with the $\mathrm{C}$ terminus of the channel. Mol Pharmacol 67:480-488

27. Michaelevski I, Chikvashvili D, Tsuk S et al (2003) Direct interaction of target SNAREs with the Kv2.1 channel. Modal regulation of channel activation and inactivation gating. J Biol Chem 278:34320-34330

28. Rettig J, Sheng ZH, Kim DK, Hodson CD, Snutch TP, Catterall WA (1996) Isoform-specific interaction of the alpha1A subunits of brain $\mathrm{Ca}^{2+}$ channels with the presynaptic proteins syntaxin and SNAP-25. Proc Natl Acad Sci U S A 93:7363-7368

29. Catterall WA (1999) Interactions of presynaptic $\mathrm{Ca}^{2+}$ channels and snare proteins in neurotransmitter release. Ann N Y Acad Sci 868:144-159 
30. Barg S, Ma X, Eliasson L et al (2001) Fast exocytosis with few $\mathrm{Ca}^{2+}$ channels in insulin-secreting mouse pancreatic B cells. Biophys $\mathrm{J}$ 81:3308-3323

31. Kanno T, Ma X, Barg S et al (2004) Large dense-core vesicle exocytosis in pancreatic beta-cells monitored by capacitance measurements. Methods 33:302-311

32. Roe MW, Worley JF 3rd, Mittal AA et al (1996) Expression and function of pancreatic beta-cell delayed rectifier $\mathrm{K}^{+}$channels. Role in stimulus-secretion coupling. J Biol Chem 271:32241-32246

33. MacDonald PE, Ha XF, Wang J et al (2001) Members of the Kv1 and $\mathrm{Kv} 2$ voltage-dependent $\mathrm{K}^{+}$channel families regulate insulin secretion. Mol Endocrinol 15:1423-1435

34. Jacobson DA, Mendez F, Thompson M, Torres J, Cochet O, Philipson LH (2010) Calcium-activated and voltage-gated potassium channels of the pancreatic islet impart distinct and complementary roles during secretagogue induced electrical responses. J Physiol 588:3525-3537

35. Yan L, Figueroa DJ, Austin CP et al (2004) Expression of voltagegated potassium channels in human and rhesus pancreatic islets. Diabetes 53:597-607
36. Xia F, Gao X, Kwan E et al (2004) Disruption of pancreatic betacell lipid rafts modifies Kv2.1 channel gating and insulin exocytosis. J Biol Chem 279:24685-24691

37. Xia F, Xie L, Mihic A et al (2008) Inhibition of cholesterol biosynthesis impairs insulin secretion and voltage-gated calcium channel function in pancreatic beta-cells. Endocrinology 149:5136-5145

38. MacDonald PE, Joseph JW, Rorsman P (2005) Glucose-sensing mechanisms in pancreatic beta-cells. Philos Trans R Soc Lond B Biol Sci 360:2211-2225

39. Rutter GA, Hill EV (2006) Insulin vesicle release: walk, kiss, pause ... then run. Physiology (Bethesda) 21:189-196

40. Aoyagi K, Ohara-Imaizumi M, Nagamatsu S (2011) Regulation of resident and newcomer insulin granules by calcium and SNARE proteins. Front Biosci 16:1197-1210

41. Hanna ST, Pigeau GM, Galvanovskis J, Clark A, Rorsman P, Macdonald PE (2008) Kiss-and-run exocytosis and fusion pores of secretory vesicles in human beta-cells. Pflugers Arch 457:1343-1350

42. MacDonald PE, Rorsman P (2007) The ins and outs of secretion from pancreatic beta-cells: control of single-vesicle exo- and endocytosis. Physiology (Bethesda) 22:113-121 